\title{
Comparative Results of DAS28 and Quality of Life in Patients with Rheumatoid Arthritis and Fibromyalgia
}

\author{
Romatoid Artrit ve Fibromiyalji Hastalarında DAS28 ve Yaşam Kalitesinin \\ Karşılaştırmalı Sonuçları
}

\author{
Filiz Sivas ${ }^{1}$, Lale Akbulut Aktekin ${ }^{1}$, Filiz Eser ${ }^{1}$, Fatma Gül Yurdakul ${ }^{1}$, Ergun Öksüz², \\ Kürşat Özoran ${ }^{1}$, Hatice Bodur ${ }^{1}$ \\ ${ }^{1}$ Ankara Numune Education and Research Hospital, Department of Physical Therapy and Rehabilitation, Ankara, Turkey \\ ${ }^{2}$ Başkent University, Family Medicine Unit, Medico Social Health Center, Ankara, Turkey
}

\section{Abstract}

Objective: In the present study, we compared Disease Activity Score 28-4v (DAS28-4v) and quality of life by using Short Form-36 (SF-36) in patients with rheumatoid arthritis (RA) and fibromyalgia (FM).

Materials and Methods: The swollen joint count (SJC) and the tender joint count (TJC) of 79 patients with RA and 34 patients with FM, the Patient Global Assessment (PGA) with $100 \mathrm{~mm}$ visual analog scale (VAS), and erythrocyte sedimentation rates (ESR) were recorded and DAS28-4v scores were calculated. The quality of life in both groups was evaluated by using SF-36.

Result: The mean DAS28-4v score of the RA group was $3.63 \pm 1.52$ (0.77-7.40) and of the FM group was $2.42 \pm 0.73$ (0.57-3.86), and the difference between groups was statistically significant $(p<0.001)$. In the Principal Component Analysis (PCA), in the RA group, the components that most affected DAS28-4v were TJC and SJC, while in the FM group, these were SJC and PGA. Significant differences were detected between the two groups in most SF-36 subgroups, except in the general mental health, social functioning and social role limitation subgroups. In the FM group, the physical function subgroup was significantly higher ( $p<0.001)$.

Conclusion: Although there is no objective injury such as inflammation or joint damage, FM can decrease the quality of life to the same extent as RA. FM, which is a non-inflammatory disease, can cause high rates in DAS28- $4 v$ due to the fact that there are many subjective complaints such as the TJC and the PGA. The intervening infections during the evaluation of disease activity in RA or concomitant diseases like FM might cause fluctuations in the DAS28-4v score.

(Turk J Rheumatol 2010; 25: 179-83)

Key words: Rheumatoid arthritis, fibromyalgia, DAS28, SF-36

Received: 19.03.2009

Accepted: 29.05.2009

\section{Özet}

Amaç: Bu çalıșmada, romatoid artrit (RA) ve fibromiyalji (FM) hastalarının Hastalık Aktivite Skorlarını 28-4v (DAS28-4v) ve Kısa Form-36 (Short Form, SF-36) kullanarak yașam kalitesi sonuçlarını karșılaștırdık.

Yöntem ve Gereçler: Otuz dört FM ve 79 RA hastasının șiș eklem sayısı (SES), hassas eklem sayısı (HES), $100 \mathrm{~mm}$ görsel ağrı skalası (GAS) ile Hasta Global Değerlendirmesi (HGD) ve eritrosit sedimentasyon hızları (ESH) kaydedildi ve DAS28-4v skorları hesaplandı. Her iki grubun yașam kalitesi SF-36 kullanılarak değerlendirildi.

Bulgular: Ortalama DAS28-4v skoru RA grubunda $3,63 \pm 1,52$ $(0,77-7,40)$ ve $\mathrm{FM}$ grubunda $2,42 \pm 0,73(0,57-3,86)$ olup gruplar arasındaki farklılık istatistiksel olarak anlamlı idi $(p<0,001)$. Temel Bileșenler Analizisinde, DAS28-4v'yi en çok etkileyen bileșenler RA grubunda HES ve SSES iken, FM grubunda SES ve HGD olarak bulundu. Genel mental sağlık, sosyal fonksiyon ve sosyal rol kısıtlanması altgrupları hariç SF-36 altgruplarının çoğunda iki grup arasında anlamlı farklılıklar saptandı. FM grubunda, fiziksel fonksiyon altgrubu anlamlı olarak daha yüksekti $(p<0,001)$.

Sonuç: Inflamasyon veya eklem hasarı gibi objektif bir hasar olmamasına rağmen, FM yașam kalitesini RA ile aynı ölçüde azaltabilir. Inflamatuvar olmayan bir hastalık olan FM, HES ve HGD gibi bir çok subjektif șikayetlerin var olması nedeniyle DAS28-4v'de yüksek skorlara neden olabilir. RA'daki hastalık aktivitesinin değerlendirilmesi sırasında araya giren enfeksiyonlar veya FM gibi eșlik eden hastalıklar DAS28-4v skorunda dalgalanmalara neden olabilir.

(Turk J Rheumatol 2010; 25: 179-83)

Anahtar sözcükler: Romatoid artrit, fibromiyalji, DAS28, SF-36

Alındığı Tarih: 19.03.2009 Kabul Tarihi: 29.05.2009

Address for Correspondence: Dr. Filiz Sivas, Ankara Numune Education and Research Hospital, Department of Physical Therapy and Rehabilitation, Ankara, Turkey Phone: +903124765545 E-mail: filiz_sivas@yahoo.com doi: $10.5152 /$ tjr. 2010.25 


\section{Introduction}

Musculoskeletal diseases such as rheumatoid arthritis (RA) and fibromyalgia (FM) are the most important chronic diseases that cause corruption in the quality of life (1). RA is a chronic systematic inflammatory disease, the main symptom of which is peripheral synovitis. Symptoms and findings of RA such as joint complaints of pain, stiffness, swelling, and fatigue, which cause functional deficiency and overall fatigue, are labile (2). However, FM is a non-articular chronic rheumatismal disease with unknown etiology, characterized by diffuse musculoskeletal pain, sleep disorder, fatigue, and a great number of tender points (3).

Quality of life is described as the individual's perception of his/her position in life with his/her own cultural background and value system and his/her relationship with his/her aims, expectations, and standards (4). To assess the life quality, several measurement methods, disease-specific or generic, have been developed (5-7). The Short Form-36 (SF-36) is a generic instrument that has been developed to identify the health condition, and it has been used recently in clinical studies as the complementary result-measuring method specific to disease (8). The SF-36 is widely used in patients with RA and $\mathrm{FM}$ in order to evaluate the quality of life $(1,4,9)$.

Monitoring and documenting disease activity in RA should be easy in daily practice and should not be timeconsuming, and the physician must be provided with sufficient information in order to make treatment decisions (10). Disease Activity Score (DAS) and its modified version, DAS28-4v, have been developed to evaluate the disease activity in RA. DAS28-4v is calculated by using swollen joint count (SJC), tender joint count (TJC), erythrocyte sedimentation rate (ESR), and the Patient Global Assessment (PGA) $(2,11)$. If there is concomitant FM in the patient with RA, then it is more difficult to evaluate the disease activity because the pain and functional disability scores are higher in these patients (12).

In the present study, DAS28-4v and SF-36 were compared in patients with RA, which is a chronic inflammatory disease, and in patients with FM, which is a chronic non-inflammatory disease.

\section{Materials and Methods}

Seventy-nine women with RA diagnosis (13) and 34 women with FM diagnosis (14) according to the American Rheumatism Association (ARA) criteria were included in the study. Informed consent was obtained from all patients.

All patients in the RA group were using single or combined disease-modifying anti-rheumatic drugs (DMARDs) such as sulfasalazine, methotrexate, chloroquine, and leflunomide. Seventy-two patients were using corticosteroids (CS) ( $\min 5 \mathrm{mg}-\mathrm{max} 10 \mathrm{mg}$ ) and all patients were using non-steroidal anti-inflammatory (NSAIDs) drugs. Sixteen patients in the FM group were using anti-depressants, while all of them were using various analgesic or NSAIDs.

Physical examination was performed on all patients. The SJC and TJC were recorded for patients in both groups. In addition, $100 \mathrm{mg}$ visual analog scale (VAS) was used for the global assessment (PGA) of all patients. The ESR of patients was measured by the standard method and DAS28-4v score was calculated for each patient.

The health-related life quality of the patients in both groups was evaluated by SF-36, the validity and safety of which was performed in Turkish (15). SF-36 is composed of eight health subsections (physical function, physical role, pain, general health, vitality, social function, emotional role, and mental health). Two total scores as physical and mental health are obtained (16). The scale is scored between " 0 " as the worst score and "100" as the best score.

In statistical analysis, normal distribution test was performed with Kolmogorov-Smirnov for both groups. In both patient groups, the item weighting and dimensionality of the score were assessed by correlation analysis as well as Principal Component Analysis (PCA). The components of DAS28 and the results of SF-36 were compared by ANOVA test in RA and FM patient groups.

\section{Results}

Of the patients recruited in the study, the mean age of the 79 patients with RA was $42.38 \pm 8.99$ years and of the 34 patients with FM was $41.82 \pm 8.29$ years, and there was no statistical difference between the two groups ( $p>0.05)$. The mean duration of disease in the RA group was $8.64 \pm 5.49$ years and in the FM group was $0.73 \pm 0.59$ years, and the difference between groups was significant $(p<0.0001)$.

In the RA and FM patient groups, DAS28-4v score showed a normal distribution in the analysis performed with Kolmogorov-Smirnov test $(z=0.621, z=0.473)$. Mean DAS28-4v score in the RA group was $3.63 \pm 1.52$ (0.77-7.40) and in the FM group was $2.42 \pm 0.73(0.57-3.86)$, and the difference between groups was statistically significant $(p<0.001)$. Both groups were compared in terms of SJC, TJC, PGA, and ESR, all of which compose DAS28. The mean SJC values were $1.25 \pm 2.44$ and $0.029 \pm 0.17$; TJC values were $4.86 \pm 6.05$ and $2.05 \pm 3.26$ : and PGA values were $4.30 \pm 2.97$ and $7.26 \pm 1.94$ in the RA and FM groups, respectively. In the comparison performed with the ANOVA test, a statistically significant difference was observed between the two groups $(p<0.01, p<0.05$, $\mathrm{p}<0.0001$, respectively). Mean ESR in the RA group was $19.39 \pm 16.51$ and in the FM group was $14.67 \pm 7.41$, and no 
Table 1. Demographic data and comparative DAS28 results in RA and FM groups

\begin{tabular}{lccc}
\hline & $\begin{array}{c}\text { RA Group } \\
(n=79)\end{array}$ & $\begin{array}{c}\text { FM Group } \\
(n=34)\end{array}$ & $p$ \\
\hline Age (years) & $42.38 \pm 8.99$ & $41.82 \pm 8.29$ & $>0.05$ \\
Disease duration (year) & $8.64 \pm 5.49$ & $0.73 \pm 0.59$ & $<0.001$ \\
TJC & $4.86 \pm 6.05$ & $2.05 \pm 3.26$ & $<0.05$ \\
SJC & $1.25 \pm 2.44$ & $0.029 \pm 0.17$ & $<0.01$ \\
ESR & $19.39 \pm 16.51$ & $14.67 \pm 7.41$ & $>0.05$ \\
PGA (VAS) & $4.30 \pm 2.97$ & $7.26 \pm 1.94$ & $<0.001$ \\
DAS28 & $3.63 \pm 1.52$ & $2.42 \pm 0.73$ & $<0.001$ \\
\hline
\end{tabular}

DAS28: Disease activity score 28, ESR: Erythrocyte sedimentation rate, PGA: Patient global assessment, SJC: Swollen joint count, TJC: Tender joint count

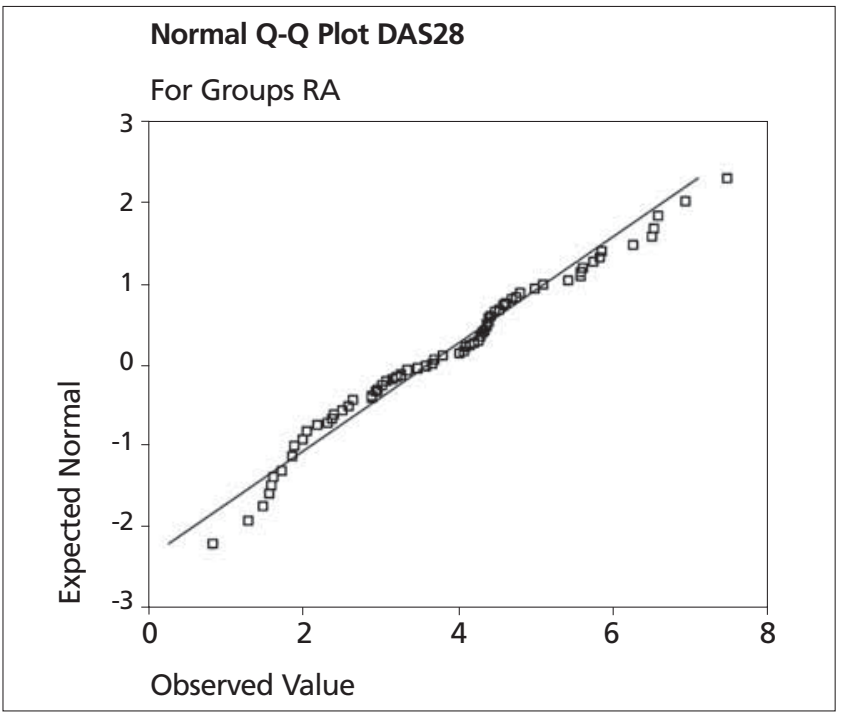

Figure 1. DAS28 showing normal distribution in the RA group

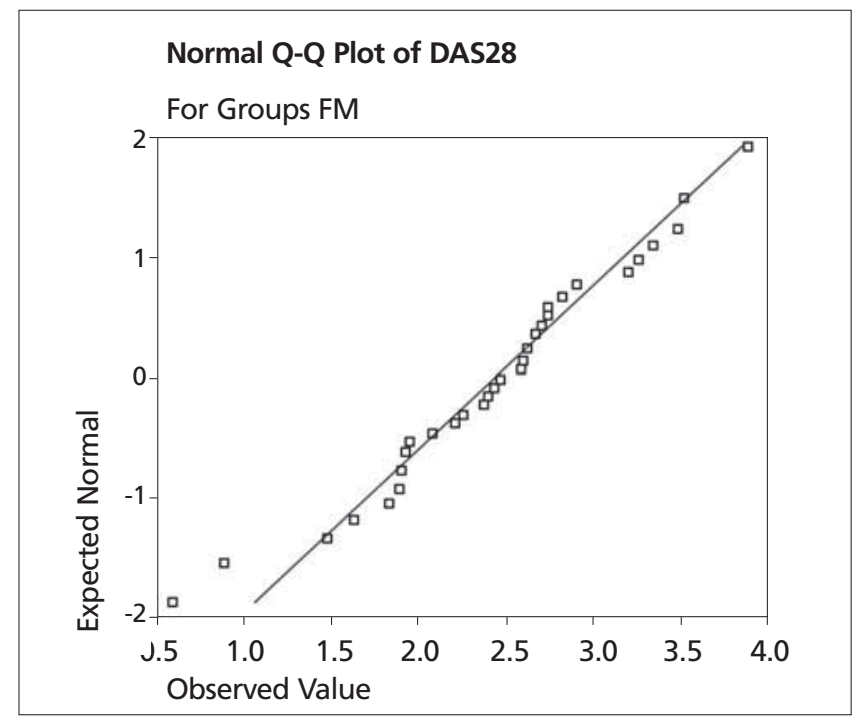

Figure 2. DAS28 showing normal distribution in the FM group statistically significant difference was found between the groups $(p>0.05)$. The results are shown in Table 1 . The distribution of DAS28-4v in FM and RA is shown in Figures 1 and 2.

In both patient groups, the item weighting and dimensionality of the score were assessed by correlation analysis as well as PCA. In the RA group, SJC, TJC, PGA, and ESR were significantly correlated with DAS28-4v ( $r: 0.690, r: 0.892, r: 0.683, r: 0.518$, respectively). However, in the FM group, while TJC and ESR were significantly correlated with DAS28-4v ( $r: 0.861, r: 0.517)$, no relation with SJC and PGA could be determined. The results are shown in Table 2.

In the RA group, according to the PCA, the components that most affected DAS28-4v were TJC and SJC, while in the FM group, the most effective components were SJC and PGA. In both groups, ESR was the component that least affected DAS28-4v. The results are shown in Table 3.

In the RA and FM patient groups, in addition to DAS28-4v, which was used to evaluate the disease activity, both groups were compared in terms of life quality by SF-36. Significant differences were determined between the two groups in all SF-36 subgroups, except in the general mental health, social functioning, and social role limitation subgroups, The physical function subgroup was significantly higher in the FM group than the RA group $(p<0.0001)$. The results are shown in Table 4.

In the RA group, a significant correlation was detected between all SF-36 subgroups and DAS28-4v. However, in the FM group, DAS28-4v was weakly correlated with the general and mental health subgroups of SF-36. The results are shown in Table 5 .

Table 2. Correlation of DAS28 with sub-components in RA and FM groups

\begin{tabular}{lcccc}
\hline & TJC & SJC & ESR & PGA (VAS) \\
\hline RA-DAS28 & $r: 0.892 * *$ & $r: 0.690 * *$ & $r: 0.518^{* *}$ & $r: 0.683^{* *}$ \\
FM-DAS28 & $r: 0.861 * *$ & $r: 0.240$ & $r: 0.517 * *$ & $r: 0.107$ \\
\hline
\end{tabular}

DAS28: Disease activity score, ESR: Erythrocyte sedimentation rate, FM: Fibromyalgia, ${ }^{*} p<0.05,{ }^{*} p<0.01$, PGA: Patient global assessment, RA: Rheumatoid arthritis, r: Correlation coefficient, SJC: Swollen joint count, TJC: Tender joint count, VAS: Visual analog scale

Table 3. Principal Component Analysis in RA-DAS28 and FM-DAS28 patients

\begin{tabular}{lcc}
\hline & RA-DAS28 & FM-DAS28 \\
\hline SJC & 0.802 & 0.778 \\
TJC & 0.870 & 0.453 \\
ESR & 0.326 & 0.161 \\
PGA & 0.768 & 0.688 \\
\hline DAS28: Disease activity & score, ESR: Erythrocyte sedimentation rate, \\
FM: Fibromyalgia, PGA: Patient global assessment, RA: Rheumatoid \\
arthritis, SJC: Swollen joint count, TJC: Tender joint count, VAS: Visual \\
analog scale
\end{tabular}




\begin{tabular}{|lccc|}
\hline \multicolumn{4}{l}{ Table 4. Comparative SF-36 results in RA and FM groups } \\
\hline & $\begin{array}{c}\text { RA Group } \\
(\mathbf{n}=79)\end{array}$ & $\begin{array}{c}\text { FM Group } \\
(\mathbf{n}=34)\end{array}$ & $\mathbf{p}$ \\
\hline Physical functioning & $58.20 \pm 29.95$ & $84.55 \pm 6.89$ & $<0.001$ \\
Physical role & $41.55 \pm 41.12$ & $20.58 \pm 16.82$ & $<0.001$ \\
Pain & $51.22 \pm 28.83$ & $32.91 \pm 14.10$ & $<0.005$ \\
General health & $38.87 \pm 20.89$ & $45.47 \pm 13.55$ & $>0.05$ \\
Vitality & $51.08 \pm 22.22$ & $25.00 \pm 15.47$ & $<0.001$ \\
Social functioning & $58.50 \pm 25.46$ & $60.79 \pm 15.76$ & $>0.05$ \\
Emotional role & $38.22 \pm 40.18$ & $25.64 \pm 24.44$ & $>0.05$ \\
Mental health & $53.97 \pm 19.10$ & $38.94 \pm 13.83$ & $<0.001$ \\
\hline RA: Rheumatoid arthritis, FM: Fibromyalgia & \\
\hline
\end{tabular}

Table 5. The correlation between DAS28 and SF-36 in RA and FM groups

\begin{tabular}{lcc}
\hline & RA-DAS28 & FM-DAS28 \\
\hline Physical functioning & $r:-0.509^{* *}$ & $r:-0.192$ \\
Physical role & $r:-0.437 * *$ & $r: 0.040$ \\
Pain & $r:-0.722 * *$ & $r:-0.229$ \\
General health & $r:-0.460 * *$ & $r:-0.294^{*}$ \\
Vitality & $r:-0.414^{* *}$ & $r:-0.233$ \\
Social functioning & $r:-0.385^{* *}$ & $r:-0.117$ \\
Emotional role & $r:-0.517 * *$ & $r:-0.011$ \\
Mental health & $r:-0.385^{* *}$ & $r:-0.317^{*}$ \\
\hline **p<0.01, *p<0.05, RA: Rheumatoid arthritis, FM: & Fibromyalgia, \\
DAS28: Disease activity score, r: Correlation coefficient & \\
\hline
\end{tabular}

\section{Discussion}

The availability of more effective treatments in RA has raised interest in the definition and assessment of the absence of disease activity or criteria for "low disease activity" (11). In RA, variables like disability and joint injury are used for the evaluation of disease activity because of the variety in symptoms. In order to measure the disease activity in RA, the DAS, which was developed in recent years and is more valid than other activity variables, is frequently used (2).

Wolfe et al. (17) investigated the presence of FM in patients with RA and could not determine any significant difference between RA patients with or without FM in terms of disease severity; however, measurements of function and pain, disease activity and the psychological status were reported to be worse in the RA-FM group. In the present study, DAS28-4v, which is developed specifically for RA and the components of which like TJC and PGA can be affected by FM, was performed on patients with FM, and their results were compared to patients with RA. Leeb et al. (10) compared DAS28 results of patients with RA and FM and found no difference between these two groups in terms of the total score. However, when the subcomponents were analyzed, significant differences were established. In the FM group, although ESR was normal and SJC was low, it was consistent with mild disease activity according to DAS28 EULAR response criterion. In the FM group, components that contributed most to DAS28 were TJC and PGA, while in the RA group, TJC, SJC, and PGA contributed at similar proportions. In the present study, total DAS28-4v score in the RA group was significantly higher than in the FM group. In the FM group, the components that contributed most to DAS28-4v were SJC and PGA, while in the RA group these were TJC and SJC. In the present study, only 1 of 34 FM patients had swelling, which was at only one joint, and this swollen joint was the most important parameter affecting DAS28-4v. All RA patients were under single or combined treatment with DMARDs, while a majority used CS. Thus, in the present study, ESR levels in patients with RA were not excessively high, so the inflammatory component of DAS28-4v remained low. DAS28-4v suggests maximal inflammatory activity in RA, while suggesting subjective complaints like pain and unsatisfactory mood in FM (10). In patients with RA, DAS28-4v alone is not sufficient for treatment decisions because the fluctuations in inflammatory activity, pain and general health status can lead to alterations in the total score (10). Especially in RA patients with secondary FM, evaluations based on subjective complaints like TJC and PGA parameters that are directly affected by the psychological mood can lead to extremely high DAS28-4v results. In the FM group, swelling of one joint and slight elevation in ESR affected DAS28-4v. This slight ESR elevation in the FM group can result from an infectious disease and could contribute negatively to the PGA.

Musculoskeletal disorders are among the most common reasons for physical disability that is a consequence of long-term severe pain and worsening quality of life (18). In these patients, various measurement methods specific to the disease have been developed in order to evaluate the quality of life and health status, along with the disease activity $(5,6)$. Generic instruments like SF-36 allow comparison of carious disease groups and the normal populations (18). Studies using SF-36 for comparing the quality of life in patients with RA and FM have reported different results $(1,9,18)$. Walker et al. (9) used SF-36 for the evaluation of quality of life in patients with RA and FM and reported that in patients with FM, all parameters except the physical function revealed lower scores. Birtane et al. (18) also used SF-36 in the comparison of RA and FM and stated that only the subgroup regarding mental health revealed a significant difference. In patients with FM, the mental health subgroup was significantly lower. However, Tander et al. (1) analyzed RA and FM patients and determined that in the FM group, the subgroups regarding physical role, social function and pain were significantly lower. In the present study, quality of life in patients with RA and FM was compared by using SF-36. Although scores of the FM 
group were worse in general, the subgroup regarding physical function was significantly higher in the FM group when compared with the RA group. In the RA group, DAS28-4v correlated significantly with all SF-36 subgroups, while in the FM group, DAS28-4v showed weak correlations only with the subgroups regarding general and mental health. The results of the present study are partially in accordance with the results of other studies $(1,9,18)$. Patients with FM report that they have more difficulties in work-related and daily-living activities than RA patients because of severe pain and physical and emotional disability (1). However, the loss in physical function resulting from the joint deformities of $\mathrm{RA}$, which is an inflammatory disease, is more than in FM, which is a noninflammatory disease.

In the present study, patients with FM and RA were compared in terms of DAS28-4v and SF-36. Although there is no objective injury such as inflammation or joint damage, FM can ruin the quality of life to the same extent as RA. FM, which is a non-inflammatory disease, can cause high rates in DAS28-4v due to the fact that there are many subjective complaints such as the TJC and the PGA. The limitations of the present study are that both study groups consisted of only female patients and further, in the RA group, patients were not evaluated in terms of secondary FM. The present authors believe that during similar studies and in clinical practice, when evaluating the DAS28-4v in patients with RA, taking into account secondary FM and other coexisting conditions, especially infections, would lead to more practical results.

\section{Conflict of Interest}

No conflict of interest declared by the authors.

\section{References}

1. Tander B, Cengiz K, Alaylı G, Ilhanlı I, Canbaz S, Cantürk F The comparative evaluation of health related quality of life and depression in patients with fibromyalgia syndrome and rheumatoid arthritis. Rheumatol Int 2002; 28: 685-91.

2. Fransen J, van Riel PLCM. The Disease Activity Score and the EULAR response criteria. Clin Exp Rheumatol 2005; 23 (Suppl 39): S93-S99.

3. Ubago Linares Mdel C, Ruiz-Pérez I, Bermejo Pérez MJ, Olry de Labry-Lima A, Hernández-Torres E, Plazaola-Castaño J. Analysis of the impact of fibromyalgia on quality of life: associated factors. Clin Rheumatol 2008; 27: 613-9.
4. Strömbeck B, Ekdahl C, Manthorpe R, Wikström I, Jacobsson L. Health-related quality of life in primary Sjögren's syndrome, rheumatoid arthritis and fibromyalgia compared to normal population data using SF-36. Scand J Rheumatol 2000; 29: 20-8.

5. Kirwan JR, Reeback JS. Stanford health assessment questionnaire modified to assess disability in British patients with rheumatoid arthritis. Br J Rheumatol 1986; 25: 206-9.

6. Burckhardt CS, Clark SR, Bennett RM. The fibromyalgia impact questionnaire: development and validation. J Rheumatol 1991; 18: 728-33.

7. Sivas F, Erçin O, Tanyolaç O, Barça N, Aydoğ S, Ozoran K. The Nottingham Health Profile in rheumatoid arthritis: correlation with other health status measurements and clinical variables. Rheumatol Int 2004; 24: 203-6.

8. Tugwell P, Idzerda L, Wells GA. Generic quality-of-life assessment in rheumatoid arthritis. Am J Manag Care 2007; 13: 224-36.

9. Walker EA, Keegan D, Gardner G, Sullivan M, Katon WJ, Bernstein D. Psychosocial factors in fibromyalgia compared with rheumatoid arthritis: I. Psychiatric diagnoses and functional disability. Psychosom Med 1997; 59: 565-71.

10. Leeb BF, Andel I, Sautner J, Nothnagl T, Rintelen B. The DAS28 in rheumatoid arthritis and fibromyalgia patients. Rheumatol 2004; 43: 1504-7.

11. Fransen J, van Riel PLCM. DAS remission cut points. Clin Exp Rheumatol 2006; 24 (Suppl 43): S29-32.

12. Naranjo A, Ojeda S, Francisco F, Erausquin C, Rúa-Figueroa I, Rodríguez-Lozano C. Fibromyalgia in patients with rheumatoid arthritis is associated with higher scores of disability. Ann Rheum Dis 2002; 61: 660-1.

13. Arnett FC, Edworthy SM, Bloch DA, McShane DJ, Fries JF, Cooper NS, et al. The American Rheumatism Association 1987 criteria for the classification of rheumatoid arthritis. Arthritis Rheum 1988; 31: 315-24.

14. Wolfe F, Smythe HA, Yunus MB, Bennett RM, Bombardier C, Goldenberg DL, et al. The American College of Rheumatology 1990 criteria for the classification of fibromyalgia. Arthritis Rheum 1990; 33: 160-71.

15. PInar R. Reliability and construct validity of the SF-36 in Turkish cancer patients. Qual Life Res 2005; 14: 259-64.

16. Kosinski M, Keller SD, Hatoum HT, Kong SX, Ware JE Jr. The SF-36 Health Survey as a generic outcome measure in clinical trials of patients with osteoarthritis and rheumatoid arthritis: tests of data quality, scaling assumptions and score reliability. Med Care 1999; 37 (Suppl): MS10-MS22.

17. Wolfe F, Cathey MA, Kleinheksel SM. Fibrositis (fibromyalgia) in rheumatoid arthritis. J Rheumatol 1984; 11: 814-8.

18. Birtane M, Uzunca K, Taștekin N, Tuna H. The evaluation of quality of life in fibromyalgia syndrome: a comparison with rheumatoid arthritis by using SF-36 Health Survey. Clin Rheumatol 2007; 26: 679-84. 